\title{
カルシウム燐酸塩とアルミノ珪酸塩との固体反応
}

\author{
市占忠利 \\ (鳴海製除株垛会社)
}

\begin{abstract}
ボーンチャイナの焼成過程を究明するための基礎資料を得ることを目的に，カルシウム燐酸塩と アルミノ珄酸塩との固体反応において，主として拡散成分と拡散方向を白金マーカー法とEPMA で決定し，また反応による各種結晶相生成過程を粉末 X線回折法で調べた.

$\mathrm{CaHPO}_{4} \cdot 2 \mathrm{H}_{2} \mathrm{O}$ から生成した $\mathrm{Ca}_{2} \mathrm{P}_{2} \mathrm{O}_{7}$ はその燐酸成分の一部が，また水酸アパタイトはその石 灰成分の一部がそれぞれアルミノ珪酸塩中に拡散して $\mathrm{Ca}_{3}\left(\mathrm{PO}_{4}\right)_{2}$ に変化した. 生成した $\mathrm{Ca}_{3}\left(\mathrm{PO}_{4}\right)_{2}$ は固相反応ではアルミノ珪酸塩と反応せず構造変化は認められなかった. 固相反応において拡散成 分のうち燐酸成分は粘土鉱物中に抾散してその融解を促進し，また石灰成分は同様に粘土鉱物中に 拡散してアノーサイトを生成した。拡散注被拡散物質の結晶構造の影響を受け，カオリナイトが最 も拡散を受け易かった．石灰成分と粘土鉱物の反応によるアノーサイトの生成における初期生成反 応性はパイロフィライト，セリサイトがカオリナイトより優れていた。 （3/4/1977 受付）
\end{abstract}

\section{Solid State Reactions of Calciumphosphates with Aluminosilicates}

\author{
Tadatoshi ICHIKO
}

(Narumi China Corporation, Nagoya-shi, 458)

\begin{abstract}
In order to collect fundamental data on mechanism of vitrification occurring in bone china bodies during firing, solid state reactions of calciumphosphates with aluminosilicates were investigated. Pt-marker method and EPMA method were used for examining the species and diffusing direction of diffusive elements, and $\mathrm{X}$-ray diffraction method was also used for determination of crystalline phases formed in the reaction.
\end{abstract}

$\mathrm{Ca}_{2} \mathrm{P}_{2} \mathrm{O}_{7}$ which was a decomposition product of $\mathrm{CaHPO}_{4} \cdot 2 \mathrm{H}_{2} \mathrm{O}$ released a part of its $\mathrm{P}_{2} \mathrm{O}_{5}$-component and made it diffuse into the aluminosilicate layer, while the remainder was transformed into $\mathrm{Ca}_{3}\left(\mathrm{PO}_{4}\right)_{2}$. Hydroxyapatite released a part of its $\mathrm{CaO}$-component and made it diffuse into aluminosilicates, while the remainder was also transformed into $\mathrm{Ca}_{3}\left(\mathrm{PO}_{4}\right)_{2}$. The $\mathrm{Ca}_{3}\left(\mathrm{PO}_{4}\right)_{2}$ was not reacted with aluminosilicates in solid state reaction and persisted stably in it. The diffusion might be affected appreciably by crystal structure of host-minerals, and the clay minerals were more reactive than the other aluminosilicates. In the solid state reactions, $\mathrm{P}_{2} \mathrm{O}_{5}$-component and $\mathrm{CaO}$-component preferentially diffused into the clay minerals and the former facilitated melting and the latter reacted with the clay minerals and formed anorthite. Kaolinite was much more reactive than the other clay minerals. In the case of forming anorthite, pyrophyllite and sericite were more reactive with $\mathrm{CaO}$-component than kaolinite.

[Received March 4, 1977]

\section{1. 緒言}

ボーンチャイナの焼成過程を究明するための基礎資料 を得ることを目的として実験を進めている過程で, カル シウム燐酸塩の二三のタイプと, 主に粘土鉱物を中心 に数種のアルミノ珪酸塩との間で特徵ある固相反応が認 められた. カルシウム燐酸塩とアルミノ珠酸塩との固相
反念については既に著者ら ${ }^{12,2\}}$ も一部反忠温度と生成結 晶相の関係を報告したが, その他には余り研究されてい ないようである. 本研究は基礎的知見を得る目的で燐酸 水素カルシウム二水塩一アルミノ珪酸塩系, 燐酸三カル シウムーアルミノ珪酸塩系, 水酸アパタイトーアルミノ珪 酸塩系の三種の系についての固相反応を検討し, 主とし 
てその間で起こる抎散について考察したのでその結果に ついて報告する。

\section{2. 実験}

\section{1 試 料}

カルシウム燐酸塩として, 燐酸水素カルシウム二水塩 ( $\mathrm{CaHPO}_{4} \cdot 2 \mathrm{H}_{2} \mathrm{O}$, 以下 $\mathrm{CHPH}$ と略記), 燐酸三カルシ ウム $\left(\mathrm{Ca}_{3}\left(\mathrm{PO}_{4}\right)_{2}\right.$, 以下 $\mathrm{C}_{3} \mathrm{P}$ と略記 $)$, 水酸アパタイト

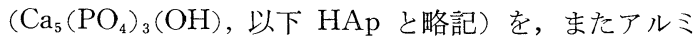
ノ珪酸塩として，カオリナイト，セリサイト，パイロフ ィライト，長石と，他に石英とアルミナを使用した．

$\mathrm{CHPH}$ は, 和光純薬特級試薬を使用し， $\mathrm{C}_{3} \mathrm{P}$ および $\mathrm{HAp}$ は $\mathrm{CHPH}$ と $\mathrm{CaCO}_{3}$ (沈降製, 和光純薬特級試 薬）から $1100^{\circ} \mathrm{C}$ 加熱により乾式合成したものを使用し $た^{3), 4)}$. カオリナイトは北海道勢多産のカオリンの水箕 物で極微量のアナターゼと石英の微粒子を含むのみの六 角板状結晶である。セリサイトは愛知県振草産のセリ少 イトの水籍物で高純度である。パイロフィライトは韓国 莞島産の原石の粉砕物で石英の混在が認められる．長石 はインド産カリ長石の粉砕物でマイクロクリーンーアル バイトのパーサイトと微量のオルソクレースである.こ れらの試料は既報1)と全く同一のものを用いたので調製 法などの詳細は省略し，成分の比較のために化学分析值 のみ 表 1 亿示した. 石英として和光純薬特級試薬の沈 降製無水珄酸を使用した．X 線回折では $\alpha$-石英であっ た.アルミナはアルコア社製 99.99\% 純度の $\alpha$-アルミ ナを使用した。

アルミノ珠酸塩系試料の窒素ガス吸着による BET 法

Table 1. Chemical composition of the raw materials (wt \%).

\begin{tabular}{|c|c|c|c|c|}
\hline & $\begin{array}{c}\text { Tokachi } \\
\text { kaolin }\end{array}$ & $\begin{array}{l}\text { Furikusa } \\
\text { sericite }\end{array}$ & $\begin{array}{c}\text { Wando } \\
\text { pyrophyllite }\end{array}$ & $\begin{array}{l}\text { Indian potash } \\
\text { teldspar }\end{array}$ \\
\hline $\mathrm{SiO}_{2}$ & 46.21 & 47.85 & 73.09 & 65.33 \\
\hline $\mathrm{TiO}_{2}$ & 1.00 & 0.40 & 0.46 & - \\
\hline $\mathrm{Al}_{2} \mathrm{O}_{3}$ & 38.09 & 33.71 & 21.95 & 18.72 \\
\hline $\mathrm{Fe}_{2} \mathrm{O}_{3}$ & 0.37 & 1.42 & 0.13 & 0.06 \\
\hline $\mathrm{CaO}$ & 0.08 & 0.33 & 0.06 & 0.11 \\
\hline $\mathrm{MgO}$ & 0.06 & 0.68 & $<0.01$ & - \\
\hline $\mathrm{K}_{2} \mathrm{O}$ & 0.14 & 9.59 & 0.06 & 12.07 \\
\hline $\mathrm{Na}_{2} \mathrm{O}$ & 0.03 & 0.50 & 0.12 & 2.78 \\
\hline Ig. loss & 14.05 & 5.12 & 4.11 & 0.39 \\
\hline Total & 100.03 & 99.60 & 99.98 & 100.06 \\
\hline
\end{tabular}

Table 2. Specific surface area determined by BET method.

\begin{tabular}{lc}
\hline & Specific surface area \\
$\left(\mathrm{m}^{2} / \mathrm{g}\right)$
\end{tabular}

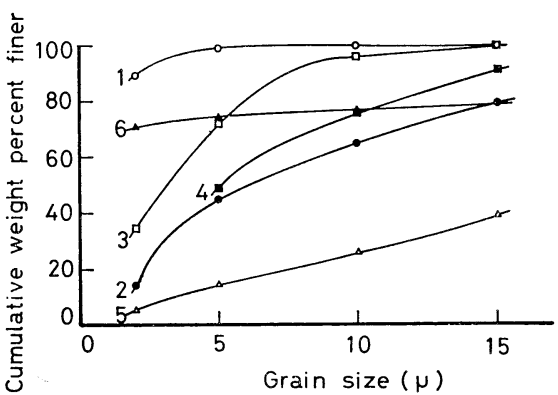

Fig. 1. Grain size distribution of the raw materials. 1: Tokachi kaolin, 2: Furikusa sericite, 3 : Wando pyrophyllite, 4 : Indian potashfeldspar, 5: Quartz, 6: Alumina.

比表面積の測定結果を 表 2 に示し，これと対比するた めに沈降法による粒度分布測定結果を 図 1 に示した。

\section{2 結晶相生成過程の $\mathrm{X}$ 線法による定性的検討}

$\mathrm{CHPH}, \mathrm{C}_{3} \mathrm{P}, \mathrm{HAp}$ の各々をアルミノ珪酸塩試料の 各々に，それぞれ $50 \mathrm{wt} \%$ 加えて 自動乳鉢で 1 時間乾 式混合を行った。この混合粉末を電気炉で $10^{\circ} \mathrm{C} / \mathrm{min} の$ 昇温速度で加熱し，㐫かじめ行った DTA，TGAの 検討結果に基づく各々の所定温度まで加熱後炉外空気中 で急冷を行い，粉末 X線回折法により生成結晶相の推移 および生成量の変化を, 各結晶相の最強ピーク強度の変 化から定性的に調べた.

\section{3 拡散性の吟味}

各原料間での成分の抬散は白金マーカー法で調べた. 錠戍は 図 2 に示した順序で作製した。まずアルミノ珪 酸塩試料の各々を $800 \mathrm{~kg} / \mathrm{cm}^{2}$ の圧力で $20(\phi) \times$ 約 10 (高) $\mathrm{mm}$ にプレス成形し (A), 直径 $0.1 \mathrm{~mm}$ の白金線 のループを境界を正しく示すように設置後 (B)，カルシ ウム燐酸塩試料粉末を入れ $1000 \mathrm{~kg} / \mathrm{cm}^{2}$ の圧力で総合 20 ( $\phi) \times$ 約 20 (高) $\mathrm{mm}$ にプレス成形し (C) 2 層錠剂を 作製した。この 2 層錠風は加熱中の接着状態を良くする ために, $10 \mathrm{~g}$ の荷重をかけた状態でマッフル電気炉内に セットし, $1150^{\circ} \mathrm{C}, 1250^{\circ} \mathrm{C}, 1300^{\circ} \mathrm{C}$ の各温度に加熱し, 各々 1 時間保持後炉内放冷した。この加熱試料はエポキ シ樹脂中に包埋し，固化後図 2 のDに示したような断面 を作製し，EPMA による測定を行った。さらに断面の 薄片を作製し，偏光顕微鏡で生成結晶相の状態を調べ

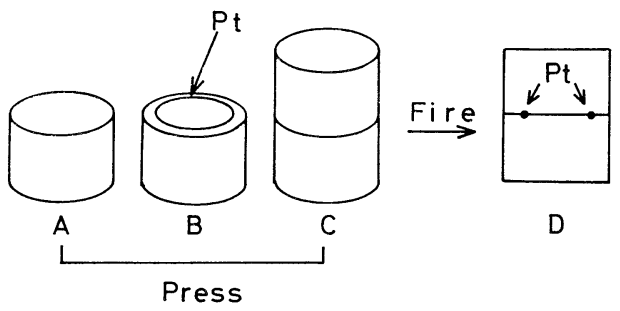

Fig. 2. The diagram showing the process of making tablet. 
た.さらに錠剤の境界面に対して平行に切断研磨面を繰 返し作製し，X線回折法で生成結晶相の変化を定性的に 調べた。

\section{3. 結 果 \\ $3.1 \mathrm{X}$ 線による結晶相生成過程の検討}

カルシウム燐酸塩とアルミノ珄酸塩系試料の各々の等 重量混合物を 2.2 の方法で各種結晶相の生成過程につ いて調べた結果をまとめて，それぞれ $\mathrm{CHPH}$ との系に ついては図 3 亿, $\mathrm{C}_{3} \mathrm{P}$ との系については図 4 に, HAp との系については図 5 に示した.

図 3 の $\mathrm{CHPH}$ の $500^{\circ} \mathrm{C}$ 以下の変化については既に

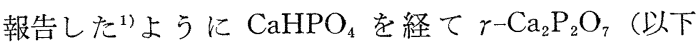
$\mathrm{Ca}_{2} \mathrm{P}_{2} \mathrm{O}_{7}$ を $\mathrm{C}_{2} \mathrm{P}$ と略記）に変化している. $\mathrm{C}_{2} \mathrm{P}$ と粘土 鉱物との反応では $\mathrm{C}_{2} \mathrm{P}$ から $\mathrm{P}_{2} \mathrm{O}_{5}$ 相当成分を放出して $\beta-C_{3} \mathrm{P}$ 亿変化し，粘土鉱物の融解が促進されている. 粘 土鉱物のらちではカオリナイトとの反応が最も進行が速 く，ついでセリサイト，パイロフィライトの順に反応速 度は遅くなっている（図 3-a，b，c)。長石とは固相反応 は明確には認められず, 長石の融解に伴って $\mathrm{C}_{2} \mathrm{P}$ の $\mathrm{C}_{3} \mathrm{P}$ 化が進行している（図 3-d)。石英とは固相反応は明確 には認为られず, $1400^{\circ} \mathrm{C}$ まで液相の生成はなかったが，

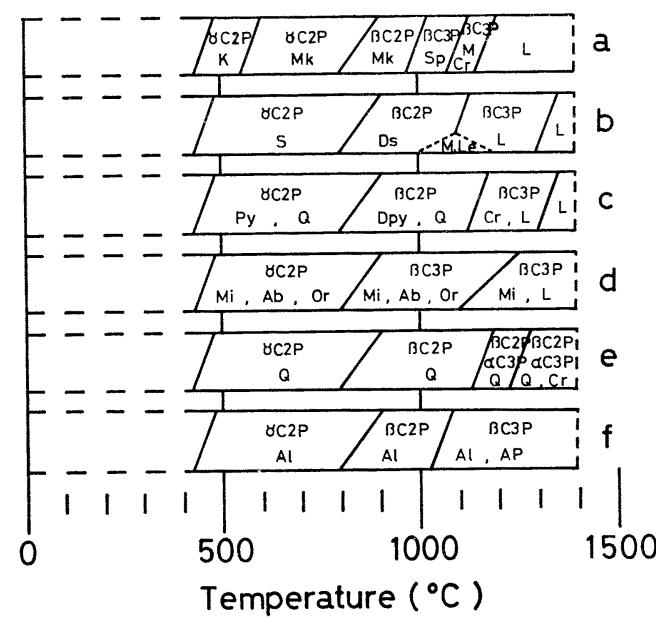

Fig. 3. The diagram showing the phase constitutions of the $\mathrm{CaHPO}_{4} \cdot 2 \mathrm{H}_{2} \mathrm{O}$-aluminosilicates system during heating.

$\gamma \mathrm{C}_{2} \mathrm{P}: \gamma-\mathrm{Ca}_{2} \mathrm{P}_{2} \mathrm{O}_{7}, \quad \beta \mathrm{C}_{2} \mathrm{P}: \beta-\mathrm{Ca}_{2} \mathrm{P}_{2} \mathrm{O}_{7}, \quad \beta \mathrm{C}_{3} \mathrm{P}$ : $\beta-\mathrm{Ca}_{3}\left(\mathrm{PO}_{4}\right)_{2}, \alpha \mathrm{C}_{3} \mathrm{P}: \alpha-\mathrm{Ca}_{3}\left(\mathrm{PO}_{4}\right)_{2}, \mathrm{~K}$ : kaolinite, $\mathrm{Mk}$ : metakaolin, $\mathrm{Sp}$ : spinel, $\mathrm{M}$ : mullite, $\mathrm{Cr}$ : cristobalite, L : liquid, S : sericite, Ds : dehydrated sericite, Le : leucite, Py : pyrophyllite, $\mathrm{Q}$ : quartz, Dpy : dehydrated pyrophyllite, $\mathrm{Mi}$ : microcline, $\mathrm{Ab}:$ albite, Or : orthoclase, $\mathrm{Al}:$ alumina, $\mathrm{AP}: \mathrm{AlPO}_{4}$

a : $\mathrm{CaHPO}_{4} \cdot 2 \mathrm{H}_{2} \mathrm{O}$-kaolinite, b : $\mathrm{CaHPO}_{4} \cdot 2 \mathrm{H}_{2} \mathrm{O}$ sericite, c : $\mathrm{CaHPO}_{4} \cdot 2 \mathrm{H}_{2} \mathrm{O}$-pyrophyllite, d : $\mathrm{CaHPO}_{4} \cdot 2 \mathrm{H}_{2} \mathrm{O}$-feldspar, e : $\mathrm{CaHPO}_{4} \cdot 2 \mathrm{H}_{2} \mathrm{O}$ quartz, f $: \mathrm{CaHPO}_{4} \cdot 2 \mathrm{H}_{2} \mathrm{O}$-alumina.

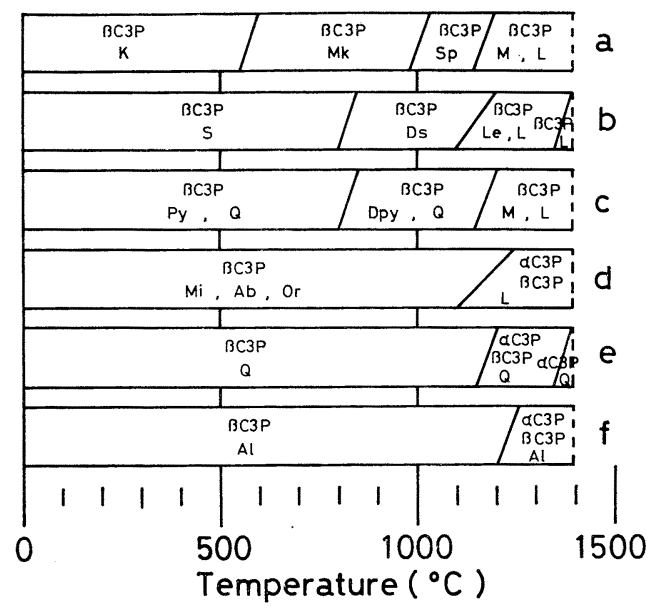

Fig. 4. The diagram showing the phase constitutions of the $\mathrm{Ca}_{3}\left(\mathrm{PO}_{4}\right)_{2}$-aluminosilicates system during heating.

$\beta \mathrm{C}_{3} \mathrm{P}: \beta-\mathrm{Ca}_{3}\left(\mathrm{PO}_{4}\right)_{2}, \alpha \mathrm{C}_{3} \mathrm{P}: \alpha-\mathrm{Ca}_{3}\left(\mathrm{PO}_{4}\right)_{2}, \mathrm{~K}:$ kaolinite, $\mathrm{Mk}$ : metakaolin, $\mathrm{Sp}$ : spinel, $\mathrm{M}$ : mullite, L : liquid, S: sericite, Ds: dehydrated sericite, Le: leucite, Py: pyrophyllite, Q : quartz, Dpy : dehydrated pyrophyllite, Mi : microcline, $\mathrm{Ab}$ : albite, Or : orthoclase, $\mathrm{Al}$ : alumina.

a : $\mathrm{Ca}_{3}\left(\mathrm{PO}_{4}\right)_{2}$-kaolinite, b : $\mathrm{Ca}_{3}\left(\mathrm{PO}_{4}\right)_{2}$-sericite, c : $\mathrm{Ca}_{3}\left(\mathrm{PO}_{4}\right)_{2}$-pyrophyllite, d: $\mathrm{Ca}_{3}\left(\mathrm{PO}_{4}\right)_{2}$-feldspar, e : $\mathrm{Ca}_{3}\left(\mathrm{PO}_{4}\right)_{2}$-quartz, f : $\mathrm{Ca}_{3}\left(\mathrm{PO}_{4}\right)_{2}$-alumina.

$1200^{\circ} \mathrm{C}$ 付近からクリストバライトの生成と一部 $\mathrm{C}_{2} \mathrm{P}$ の $\mathrm{C}_{3} \mathrm{P}$ への変化が認められた(図 3-e)。アルミナとは $1050^{\circ} \mathrm{C}$ 付近から $\mathrm{C}_{2} \mathrm{P}$ の $\mathrm{C}_{3} \mathrm{P}$ への変化に伴いアルミナ の一部が燐酸と反応して燐酸アルミニウムを生成した (図 3-f).

図4の $\mathrm{C}_{3} \mathrm{P}$ との反応の結果にはいずれの場合も固相 反応が起こったと考えられる明らかな結果は認められな かった.しかし $\mathrm{C}_{3} \mathrm{P}$ とアルミノ珪酸塩が熔け始める温 度の低下が認められた，一方石英とアルミナとには反応 は認められなかった。

図 5 の HAp との反応では粘土鉱物との反応で約 $1000^{\circ}$ $\mathrm{C}$ 以上で $\mathrm{HAp}$ の $\mathrm{CaO}$ 相当成分の放出に相当する $\mathrm{C}_{3} \mathrm{P}$ 化と,さらにアノーサイト生成が認礼れた（図 5-a, b，c). またアノーサイトの生成反忘はカオリナイトが最 も早い時期に始まるが，初期反応速度はパイロフィライ ト，セリサイトが急速であった。長石との反応でも $\mathrm{C}_{3} \mathrm{P}$ の生成とアノーサイトの生成が認められたが, 長石の融 解によるアノーサイトの再結晶化によるものか固相反応 によるものかは明らかにできなかった（図 5-d). 石英 およびアルミナとでは反応は認められず, $1100^{\circ} \mathrm{C}$ 付近 から $\mathrm{HAp} の \beta-\mathrm{C}_{3} \mathrm{P}$ と $\mathrm{Ca}_{4} \mathrm{P}_{2} \mathrm{O}_{9}$ (以下 $\mathrm{C}_{4} \mathrm{P}$ と略記) への分離のみが認められた（図 5-e,f）。 


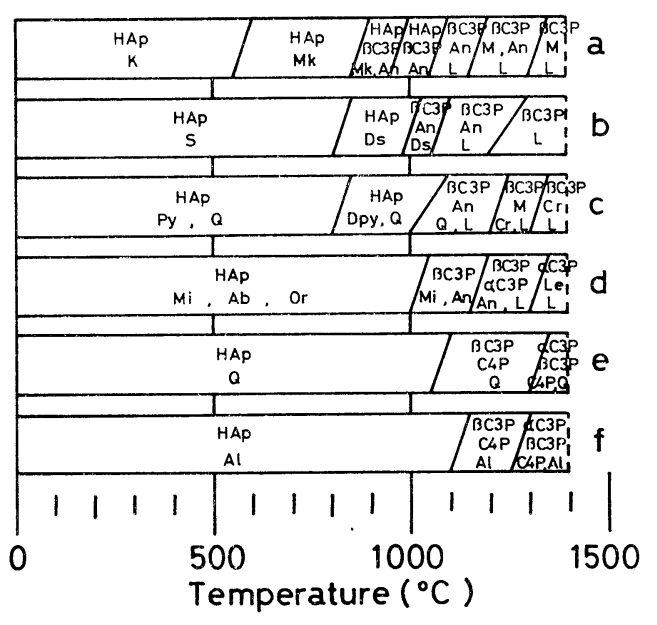

Fig. 5. The diagram showing the phase constitutions of the hydroxyapatite-aluminosilicates system during heating.

HAp : hydroxyapatite $\left(\mathrm{Ca}_{5}\left(\mathrm{PO}_{4}\right)_{3}(\mathrm{OH})\right), \beta \mathrm{C}_{3} \mathrm{P}$ : $\beta-\mathrm{Ca}_{3}\left(\mathrm{PO}_{4}\right)_{2}, \alpha \mathrm{C}_{5} \mathrm{P}: \alpha-\mathrm{Ca}_{3}\left(\mathrm{PO}_{4}\right)_{2}, \quad \mathrm{C}_{4} \mathrm{P}: \mathrm{Ca}_{4} \mathrm{P}_{2} \mathrm{O}_{9}$, $\mathrm{K}$ : kaolinite, $\mathrm{Mk}$ : metakaolin, An: anorthite, $\mathrm{M}$ : mullite, L : liquid, S : sericite, Ds : dehydrated sericite, Py : pyrophyllite, Dpy : dehydrated pyrophyllite, Q : quartz, $\mathrm{Cr}$ : cristobalite, $\mathrm{Mi}$ : microcline, Ab:albite, Or: orthoclase, Le : leucite, Al : alumina.

a : hydroxyapatite-kaolinite, b: hydroxyapatitesericite, c : hydroxyapatite-pyrophyllite, d: hydroxyapatite-feldspar, e : hydroxyapatitequartz, $f:$ hydroxyapatite-alumina.

\section{2 固相反応における拡散}

$\mathrm{CHPH}, \mathrm{C}_{3} \mathrm{P}, \mathrm{HAp}$ の各々とアルミノ珪酸塩系試料の 固相反応に扑ける拡散成分を白金マーカー法で調べた。

図 6,7 亿 $\mathrm{CHPH}$-アルミノ珪酸塩系についての EPMA による線走査の結果を示した。 CHPH とカオリナイト の反応では図 6-A と図7 亿示したように明らかに燐成 分のカオリナイト側への拡散が認められた．固相-液相 反応では EPMA の線走查の結果から石灰成分のカオリ ナイト側への拡散も認められた。 セリサイト，パイロフ ィライトとの結果もカオリナイトに類似した結果を示し ているが，拡散成分の拡散量はいずれもカオリナイトよ り少なかった．長石との反応は固相間では認められず (図 6-B), 長石の熔融に伴ら液相の発達に伴って, 石灰 成分と燐成分が長石側へ抎散している．石英との反応は 図6-Cに示したように認められなかった。アルミナとは 図 6-D に示したように燐成分のアルミナ側への拡散が 認められ，アルミナ側接触面に $\mathrm{AlPO}_{4}$ の生成が $\mathrm{X}$ 線回 折により認められた. $\mathrm{CHPH}$ 側の変化は上述したよう に粘土鉱物とアルミナへの燐成分の拡散により $\mathrm{C}_{3} \mathrm{P}$ が 生成し,接触面に近いところでは $\mathrm{C}_{3} \mathrm{P}$ のみが存在し，接 触面から離れるに従い $\mathrm{C}_{2} \mathrm{P}$ と共存し，ついには未反応と 推測される $\mathrm{C}_{2} \mathrm{P}$ のみの存在層が認められた. 図 8 は力
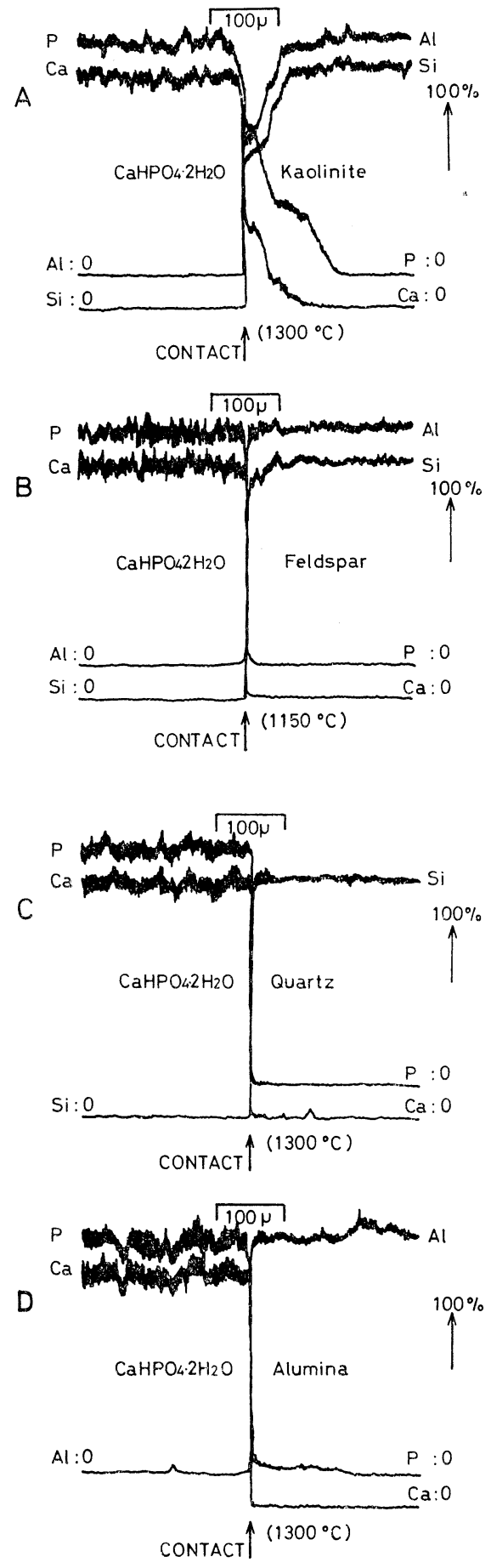

Fig. 6. EPMA scans for $\mathrm{CaHPO}_{4} \cdot 2 \mathrm{H}_{2} \mathrm{O}-$ aluminosilicates contact.

オリナイトとの反応により生成した $\mathrm{C}_{3} \mathrm{P}$ の樹枝状結晶 の偏光顕微鏡写真である. $1300^{\circ} \mathrm{C}$ で汶約 $0.1 \mathrm{~mm}$ に層 は発達した. 長石との場合は固相-液相反応による $\mathrm{C}_{3} \mathrm{P}$ のみの層は認められず，接触面から $\mathrm{C}_{3} \mathrm{P}$ と $\mathrm{C}_{2} \mathrm{P}$ の共存 

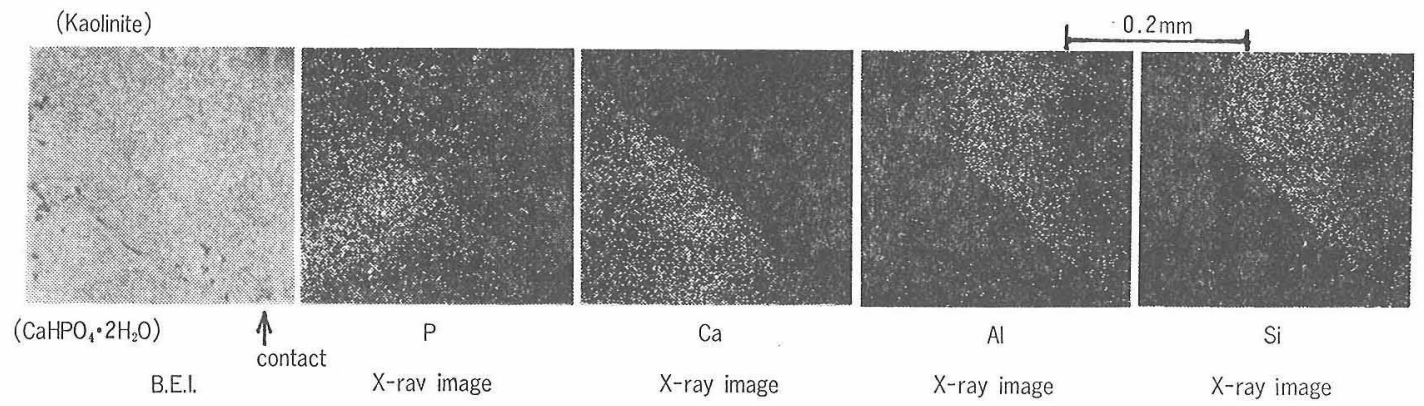

Fig. 7. EPMA photographs of back-scattered electron image and $\mathrm{X}$-ray images of $\mathrm{CaHPO}_{4} \cdot 2 \mathrm{H}_{2} \mathrm{O}$-kaolinite contact in the specimen heated at $1150^{\circ} \mathrm{C}$ for $1 \mathrm{~h}$.

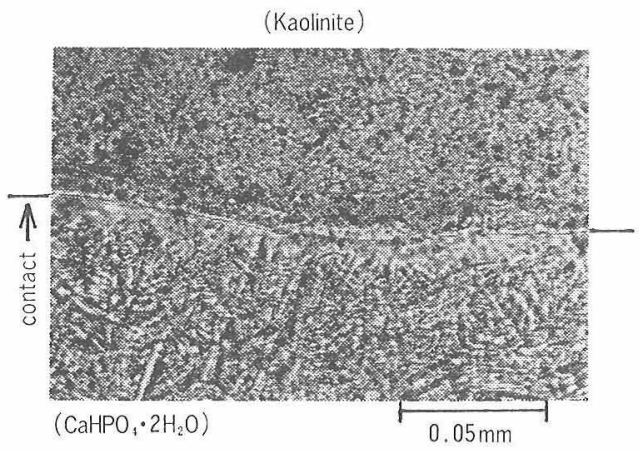

Fig. 8. Polarization microphotograph of $\mathrm{CaHPO}_{4}$. $2 \mathrm{H}_{2} \mathrm{O}$-kaolinite contact in the specimen heated at $1300^{\circ} \mathrm{C}$ for $1 \mathrm{~h}$.

層から $\mathrm{C}_{2} \mathrm{P}$ 層への変化が認められた，石英とは区応が なく, 従って $\mathrm{C}_{2} \mathrm{P}$ 層のみが存在した.

図 9 には $\mathrm{C}_{3} \mathrm{P}-ア ル ミ ノ$ 珪酸塩系についての EPMA の結果を示した. 図 9-A, B に代表されるよらに, この 系に掠いては固相反応による成分移動は聲められなか。 た.

図 10 には HAp-アルミノ珪酸塩についての EPMA の結果を示した. HAp は図 10-A に代表されるように カオリナイト，セリサイト，パイロフィライトとの閒で 石灰成分の粘土鉱物側への拡散が起こっていることが認 められ，粘土鉱物側でのアノーサイト生成がX線回折に よって認められた。また長石とは図 10-Bに示したよう そ固相区応での石灰成分の拡散は認められなかったが, 長石熔融化に伴う固相-液相反応下で石灰成分の長石侧 への拡散が認められた，石英，アルミナとの間には図 10-C で代表されるように固相反応に上る成分移動注 められなかった。 また HAp とアルミノ珪酸塩との反応 で固相-液相下の反応では石灰成分の他に燐成分の液相 への拡散が認められた。

HAp 側の変化は: 固相反応による石灰成分の抬散によ り HAp は $\mathrm{C}_{3} \mathrm{P}$ に変化し, CHPH の場合と同様に接 触面付近に $\mathrm{C}_{3} \mathrm{P}$ の層を形成し，接触面少ら離れるに従 って HAp が共存し, HAp のみの層に移行している. また HAp は温度が上昇（約 $1300^{\circ} \mathrm{C}$ 以上）すると
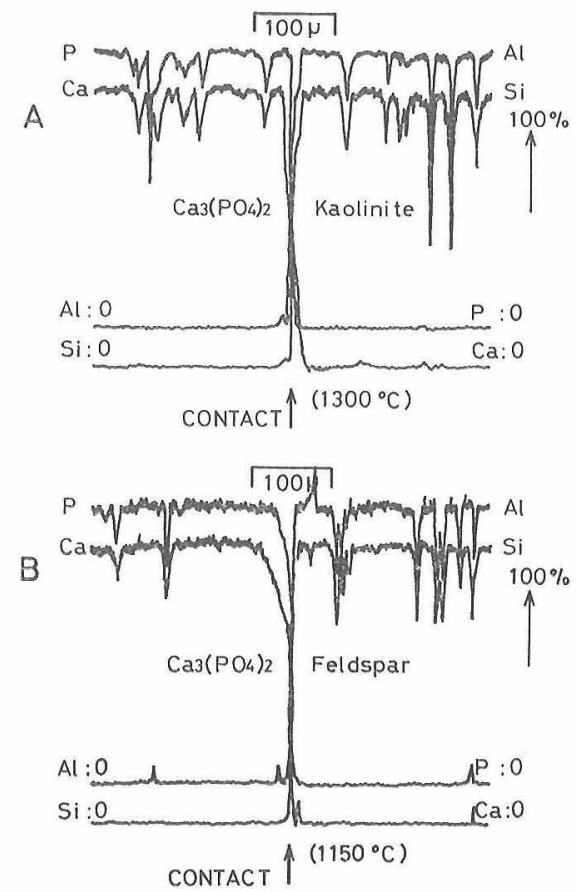

Fig. 9. EPMA scans for $\mathrm{Ca}_{3}\left(\mathrm{PO}_{4}\right)_{2}$-aluminosilicates contact.

$\mathrm{C}_{4} \mathrm{P}$ と $\mathrm{C}_{3} \mathrm{P}$ に分離した。 固相一液相間による石灰成分 と燐成分が拡散する場合は $\mathrm{C}_{3} \mathrm{P}$ の外の層は存在せず。 $\mathrm{C}_{3} \mathrm{P}$ と HAp の共存になり，これも $\mathrm{CHPH}$ の場合と 類似した傾向を示した。

\section{4. 考察}

\section{$4.1 \mathrm{CHPH}$ とアルミノ珪酸塩における固相反応}

$\mathrm{CHPH}$ とアルミノ理酸塩との反応では粘土鉱物およ びアルミナとの閒に固相反応による成分移動が認められ た.すなわち $\mathrm{C}_{2} \mathrm{P}$ とカオリナイト，セリサイト，パイ ロフィライトの脱水物掠よびアルミナとの閂の燐酸成分 の拡散である.この現象は既報1で燐酸成分の移動の推 測で一部報告しているが，本実験により実証されたこと になる。 

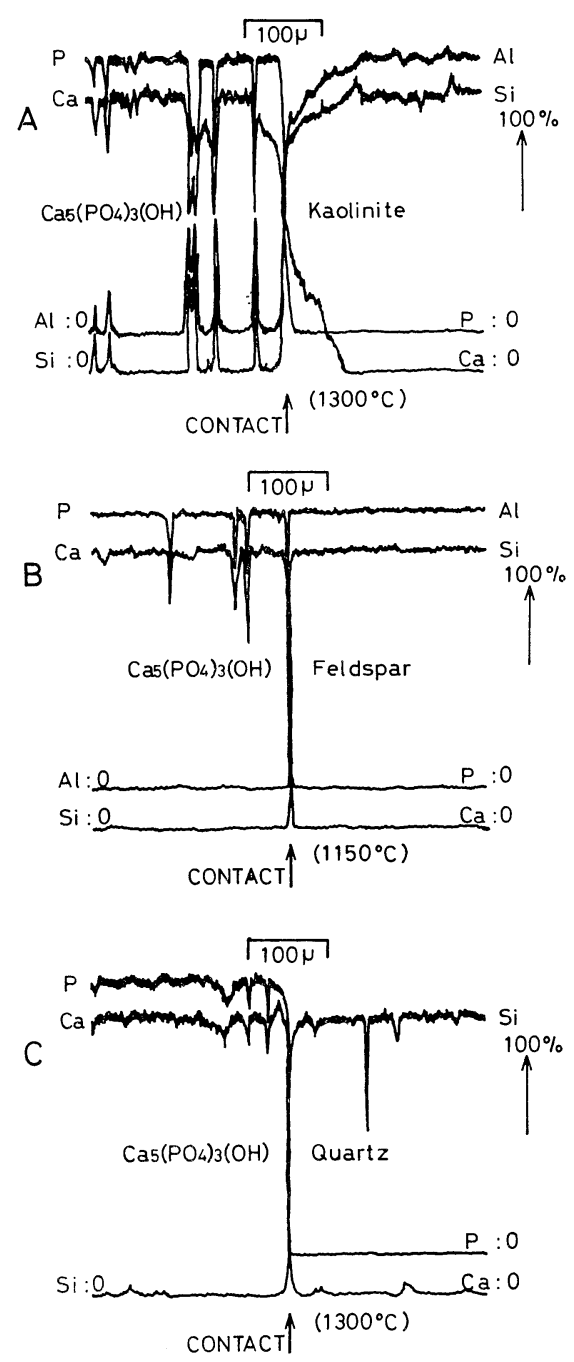

Fig. 10. EPMA scans for hydroxyapatitealuminosilicates contact.

$\mathrm{C}_{2} \mathrm{P}$ から拡散する燐酸成分は被拡散物質の結晶構造の 違いによって反応に差異が生じていると考えられる すなわち化学成分的に類似しているセリサイトと長石で は固相反応でセリサイトに反応が認められ, 長石に認め られないことから, 粘土鉱物に代表される層状珄酸塩へ の拡散が推測でき.さらにカオリナイトとパイロフィラ イトは共にアルミナー珠酸系層状珪酸塩であるが, $1: 1$ 型構造のカオリナイトの方が, $2: 1$ 型構造のパイロフィ ライトより反応性が大きく, 結晶構造の違いが反応に影 響することが推測できる. 燐酸成分の拡散の違いをタイ プ分けすると図 11 に示すようになる. タイプBのアル ミナは別として, タイプAについては上述したように被 拡散物質の結晶構造の違いにより反応はカオリナイトが 最も大きく, セリサイト, パイロフィライトはやや劣っ ている.

カオリナイトの脱水物であるメタカオリンの単位胞中

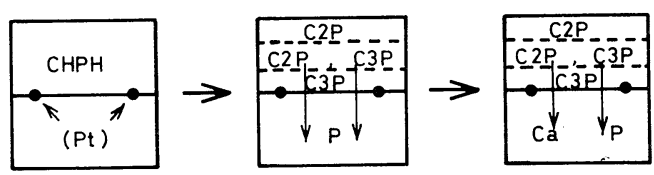

1. Type A : kaolinite, sericite, pyrophyllite

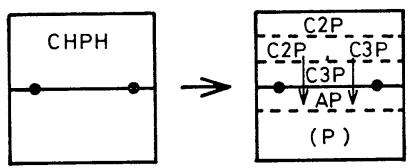

2. Type B : alumina

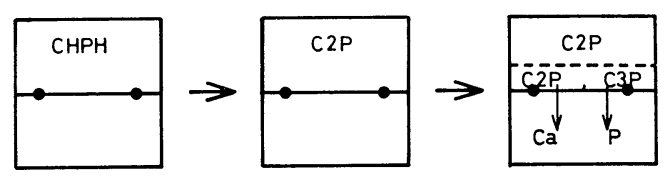

3. Type $\mathrm{C}$ : feldspar

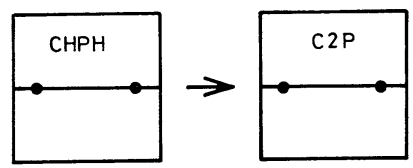

As

Bs

Cs

4. Type D : quartz

Fig. 11. The diagram showing the type of reactions for $\mathrm{CaHPO}_{4} \cdot 2 \mathrm{H}_{2} \mathrm{O}$-aluminosilicates system. $\mathrm{CHPH}: \mathrm{CaHPO}_{4} \cdot 2 \mathrm{H}_{2} \mathrm{O}, \mathrm{C}_{2} \mathrm{P}: \mathrm{Ca}_{2} \mathrm{P}_{2} \mathrm{O}_{7}, \mathrm{C}_{3} \mathrm{P}$ : $\mathrm{Ca}_{3}\left(\mathrm{PO}_{4}\right)_{2}$. As : unfired, Bs : solid state reaction, $\mathrm{Cs}$ : solid-liquid reaction.

の原子の配列様式は $\mathrm{O}_{6} \mathrm{Si}_{4} \mathrm{O}_{6} \mathrm{Al}_{4} \mathrm{O}_{2}{ }^{6)}$ でさらに $1000^{\circ} \mathrm{C}$ 付近では一部 $\mathrm{Si}-\mathrm{Al}$ スピネルの生成が認められ, この 生成に伴って $\mathrm{SiO}_{2}$ 成分が放出される.

一方パイロフィライトは脱水によって $\mathrm{Al}(\mathrm{O}, \mathrm{OH})$ 八 面体が僅かに再配列されるだけでその単位胞中の配列様 式は $\mathrm{O}_{6} \mathrm{Si}_{4} \mathrm{O}_{5} \mathrm{Al}_{4} \mathrm{Si}_{4} \mathrm{O}_{6}{ }^{7)}$,8) であり, その構造はメタカオ リンよりも安定と考えられる ${ }^{5)}$ ままたセリサイトは層間 イオンの相違はあるけれど, 基本構造はパイロフィライ トに類似している. 従ってこの被拡散物質の構造の安定 性の相違が反応性に影響していると推測できる.

\subsection{HAp とアルミノ珪酸塩における固相反応}

$\mathrm{HAp}$ とアルミノ珪酸塩の固相反応は $\mathrm{CHPH}$ の場合 と同様に粘土鉣物に代表される層状珪酸塩との間に認め られた. HAp との反応をタイプ分けすると図 12 に示 すようになる。

HAp から拡散する石灰成分は 4.1 の記述と同様に被 拡散物質の構造の相違によってその反応性は影響を受け ているようである. 石灰成分の拡散の開始時期について は 4.1 で述べた構造の相違によりカオリナイトが比較的 早くから反応しているが, 初期反応における反応性は傾 向を異にしているようである.すなわち拡散成分である 


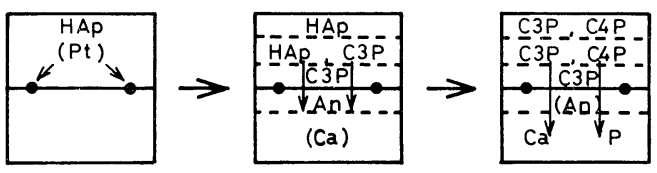

1. Type A : kaolinite, sericite, pyrophyllite

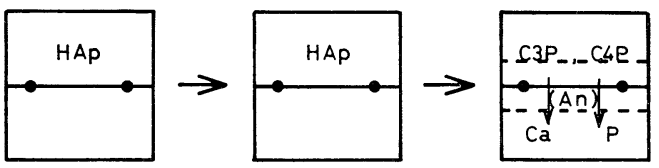

2. Type B : feldspar

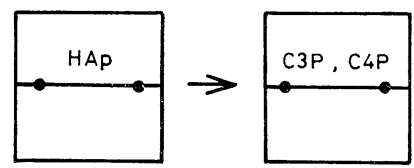

As

Bs

Cs

3. Type $\mathrm{C}$ : quartz, alumina

Fig. 12. The diagram showing the type of reactions for hydroxyapatite-aluminosilicates system. HAp : hydroxyapatite $\left(\mathrm{Ca}_{5}\left(\mathrm{PO}_{4}\right)_{3}(\mathrm{OH})\right), \mathrm{C}_{3} \mathrm{P}$ : $\mathrm{Ca}_{3}\left(\mathrm{PO}_{4}\right)_{2}, \quad \mathrm{C}_{4} \mathrm{P}: \mathrm{Ca}_{4} \mathrm{P}_{2} \mathrm{O}_{9}, \mathrm{An}:$ anorthite, As : unfired, Bs: solid state reaction, $\mathrm{Cs}$ : solid-liquid reaction.

石灰成分は被拡散成分である粘土鉱物の脱水物と反応し てアノーサイトを生成するのであるが，この場合，井上 らの石灰とディッカイト, パイロフィライトの固体反応 の報告 ${ }^{5)}$ で, 被拡散物質とアノーサイトの間の結晶学的 関連に扔いて, よりアノーサイトの原子配列に近い構造 を持つものが石灰成分を捕捉しやすく，パイロフィライ 卜が反応性に優れていると言っていることから, 本研究 の場合む同様にパイロフィライト，七リサイトがカオリ ナイトより初期反応の反応性が優れていたものと推測で きる.

4.3 アルミノ珪酸塩中でのカルシウム燐酸塩の熱安 定性

$\mathrm{CHPH}, \mathrm{C}_{3} \mathrm{P}, \mathrm{HAp}$ の各カルシウム燐酸塩とアルミノ 珪酸塩との反応の検討の結果, $\mathrm{CHPH}$ は $\mathrm{C}_{2} \mathrm{P}$ に変化し た後, アルミノ珪酸塩中およびアルミナに燐酸成分の一 部が拡散し， $\mathrm{C}_{3} \mathrm{P}$ に変化し ${ }^{1)}$, また HAp もアルミノ珪酸 塩中に石灰成分の一部が搪散し， $\mathrm{C}_{3} \mathrm{P}$ に変化している ${ }^{9)}$. また $\mathrm{C}_{3} \mathrm{P}$ は反応によって構造変化をしていない， $\mathrm{C}_{2} \mathrm{P}$, $\mathrm{C}_{3} \mathrm{P}, \mathrm{HAp}$ はいずれも単独では熱的に安定な結晶である $か^{11,4)}$, 層状珪酸塩との共存下では $\mathrm{C}_{2} \mathrm{P}$ および $\mathrm{HAp}$ は熱的に安定性を失い，それぞれ固相反応下で燐酸成分
又は石灰成分の一部を放し， $\mathrm{C}_{3} \mathrm{P}$ に変化するようであ り， $\mathrm{C}_{3} \mathrm{P}$ が最も安定な構造を持っていることが推測され る.

\section{5. 総 括}

カルシウム燐酸塩とアルミノ珪酸塩との固相反応に扝 ける拡散成分の拡散方向を白金マーカー法で決定し, ま た各配合物の反応を粉末 $\mathrm{X}$ 線回折法で調べ結晶生成の変 化を調べた.

得られた結果を要約すると次の通りである.

(1) 燐酸水素カルシウム二水塩はピロリン酸カルシ ウムに変化後, 層状珪酸塩側に燐酸成分を一方拡散さ せ，燐酸三カルシウムを生成する。

（2）水酸アパタイトは層状珄酸塩側に石灰成分を一 方拡散して燐酸三カルシウムとなり, 石灰成分は被拡散 物質と反応して, 粘土鉱物の場合はアノ一サイトを生成 する。

（3）カルシウム燐酸塩はアルミノ珪酸塩中では燐酸 三カルシウムが熱的に最も安定な結晶構造であると推定 できる.

（4）拡散による拡散成分の反応性は被拡散物質の結 晶構造の影響を受ける. 燐酸成分の拡散はカオリナイト が優先し,反応性も大きいが,石灰成分の拡散は拡散の開 始温度はカオリナイトが早いが, 初期反応の反応性はパ イロフィライト，セリサイトの方が大きいようである。

謝辞本研究に発表の機会をいただいた鳴海製陶 (株) 石原洌専務取締役はじめ關係の方々に感謝の意を表しま す. また研究をまとめるにあたり終始御指導を賜わりました東 京工業大学工業材料研究所 浜野健也教授に心から感謝しま す.さらに研究遂行にあたって御助言を賜わりました東京都立 大学工学部 金澤孝文教授ならびに 名古屋大学理学部 都築芳 郎博士，また御協力を賜わりました鳴海製陶（株）研究室の方 々に感謝の意它表します.なお EPMA 装置は名古屋大学理学 部を利用させていただいた。重礼て感謝の意を表します。

1976 年 第 14 回窒業基礎討論会で一部発表.

\section{文献}

1）市古忠利, 晏協, 84, 186-93 (1976).

2) 市古忠利, 磯野赳夫, 望月敬一, 割協, 85, 218-25(1977).

3）金澤孝文，七ラミックス，1，583-87 (1966).

4）书古忠利，石膏と石灰，投稿中.

5）井上圭吉，奥田 進，窐協，81，507-12 (1973).

6) G.W. Brindley, R. Wardle, J. Am. Ceram. Soc., 42, 314-18 (1959).

7) G.W. Brindley, R. Wardle, Am. Mineral., 55, 125972 (1970).

8) R. Wardle, G.W. Brindley, ibid., 57, 732-50 (1972).

9) P.D.S.St. Pierre, J. Am. Ceram. Soc., 38, 217-22 (1955). 